\title{
ESTIMATION OF FIRING TEMPERATURE OF ISLAMIC CERAMIC USING XRD AND FTIR
}

\author{
Hamada SADEK \\ Faculty of Archaeology, Fayoum University, Egypt. \\ E-mail: hsr00@fayoum.edu.eg
}

\begin{abstract}
Firing minerals plays an important role in the estimation of firing temperature and thermal transformation in ceramic components. In this study, a comparison between XRD and FTIR was used in order to identify the firing minerals of ceramic from Al-Fūstāț, Cairo (641-1168 AD). Two types of minerals described in this study, meta-stable minerals (e.g. Gehlenite and Wollastonite), and stable minerals (e.g. Diopside). The thermal minerals are an indicator of the firing temperature of archaeological ceramic. All selected objects were fired above 850$900{ }^{\circ} \mathrm{C}$. The results indicate that the ceramic from Mamlūk period has high quality of production. Firing at high temperature produce hard ceramic that requires special conservation materials when it applied.
\end{abstract}

\section{KEYWORDS}

Ceramics; Firing minerals; Temperature; Mamlūk; XRD; FTIR; Diopside; Secondary calcite

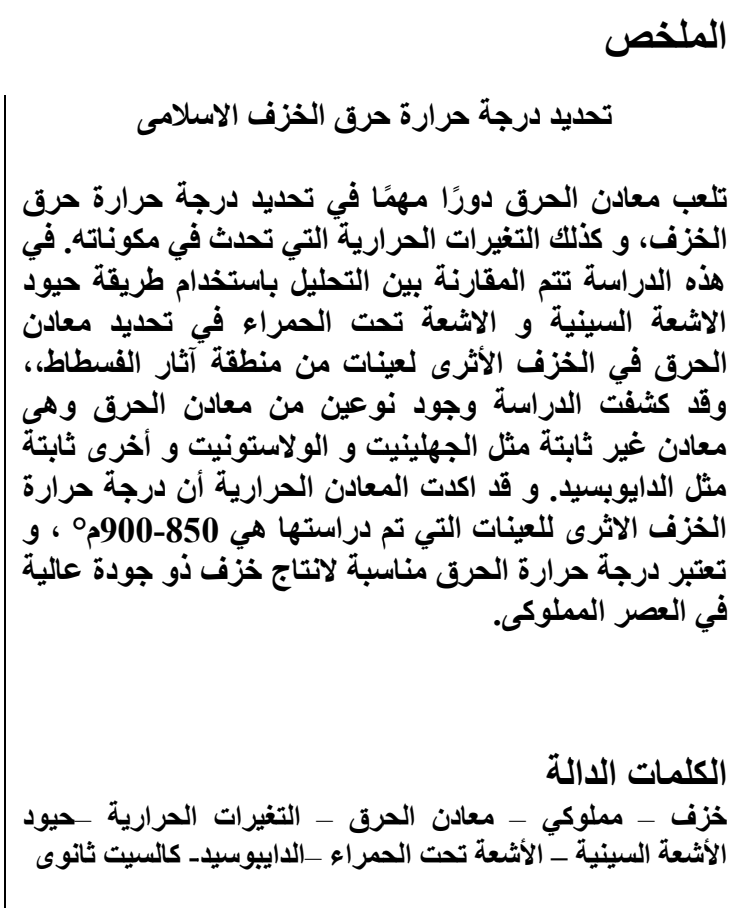

\section{INTRODUCTION}

Ceramic is one of the most common materials that archaeologists and conservators find in the excavation sites. Research studies on Ceramic are considered as the alphabetical of archaeology due to the valuable historical, social, economic and technological information obtained. Clay is the main raw material of ceramic while various additives, such as sand, shells, limestone powder, crushed rock and other organic materials, were added to enhance 
the properties of the ceramic product. ${ }^{1}$ Additives aim to reduce the shrinkage of clay mixture and improve the workability of the raw material during the shaping process. Clay and tempers were mixed to form the shape, then dried, decorated and finally fired at the proper temperature. The purpose of firing process during the production of ceramic is to transform the clay into solid and irreversible material against the effect of water. ${ }^{2}$

The mineralogical compositions of the ceramic classified into three groups; 1) primary minerals that come from the raw materials, 2) firing minerals formed after firing at specific firing temperatures, and 3) depositional minerals, which formed in the burial environment. The production of ceramic passes through few stages starting with the drying process to remove the physical water. The water that lubricates clay platelets is usually evaporates first followed by the water that chemically joints in the clay mineral structure ${ }^{3}$. Caution should be taken into consideration during the drying process to avoid stresses caused by drying rapidity, which may produce cracks and other internal stresses ${ }^{4,5}$. After drying, the decompositions of clay and additives will occur due to the oxidation during the early stages of heating with the presence of oxygen in the kiln. With a low ratio of impurities, sintering of the components will take place before vitrification where the outer edges of quartz grains start to melt and overlap, with increasing of the density and decreasing of porosity. By increasing the firing temperature, vitrification takes place and the body of the ceramic product gets harder. At this stage, other components in the clay such as quartz and alkaline oxides melt and iron oxides became part of glass phases in the body of the product. The vetrification reaches its highest level in production of porcelain objects ${ }^{6}$. The firing temperature is considered as a dominant factor in transforming clay into a stable material through permanent physio-chemical changes of the clay compositions. Chemical changes occur when the clay fired at high temperatures, gaining stability and irreversibility against water effects. ${ }^{7}$

Various studies carried out to estimate the firing temperature of ceramic to observe the hardness and density, thermal expansion and shrinkage of the product in assessing the technology of pottery in ancient ages that reveal the development of techniques. Furthermore, the firing temperature of ceramic is a good indication of the economy, since high firing needs a huge amount of materials as source for the kiln heat ${ }^{8}$. Additional methods used for the firing temperature estimation which include ${ }^{9}$ i) measurement of the coercive force and saturation magnetization of ceramic ii) the microstructure observation of ceramic matrix through sintering and vitrification by $\mathrm{SEM}^{10}$. While no adequate research was conducted on the accurate range of firing temperature used in ceramic production ${ }^{11}$. The disadvantage of methods used in the previous studies is the limited accuracy. FTIR spectroscopy is a technique based on the vibrations of the atoms of a molecular ${ }^{12}$, and

1- Rapp, Archaeomineralogy, p.183.

2- Nicholson, Kilns and Firing Structures, pp.1-10

3- Rice, Pottery analysis, pp. 375-386.

4 - Henderson, The science and archaeology of materials, p.122.

5 - Shepard, Ceramics for archaeologists, p.70.

6 - Rhodes, Clay and glazes for the potters, p. 47.

7 - Maniatis, The emergence of ceramic technology, pp. 11-28.

8 - Goodwin et al., Assessing Techniques for the Estimation of Original Firing Temperatures of Plains Ceramics, pp.180-204.

9 - Rasmussen et al., pottery firing temperatures, pp1705-1716.

10 Chatfield, Tracing firing technology through clay properties in Cuzco, pp727-736.

11 - Velraj et al., Estimation of firing temperature of some archaeological ceramics, pp730-733.

12 - Stuart, Infrared Spectroscopy, p.48.

- 168 - Estimation of firing temperature of Islamic ceramic using XRD and FTIR 
represents a powerful technique providing a molecular fingerprint of ceramic composition minerals. The main aim of this article is to identify firing minerals in the Islamic ceramic from Cairo to estimate firing temperature of ceramic by means of FTIR and XRD. In this study, measurements will focus on determination of the firing minerals during burning raw materials. Via these techniques, archaeologists and curators, historian etc. will be able to understand the ancient technology of archaeological potteries during the Mamlūk period in Egypt.

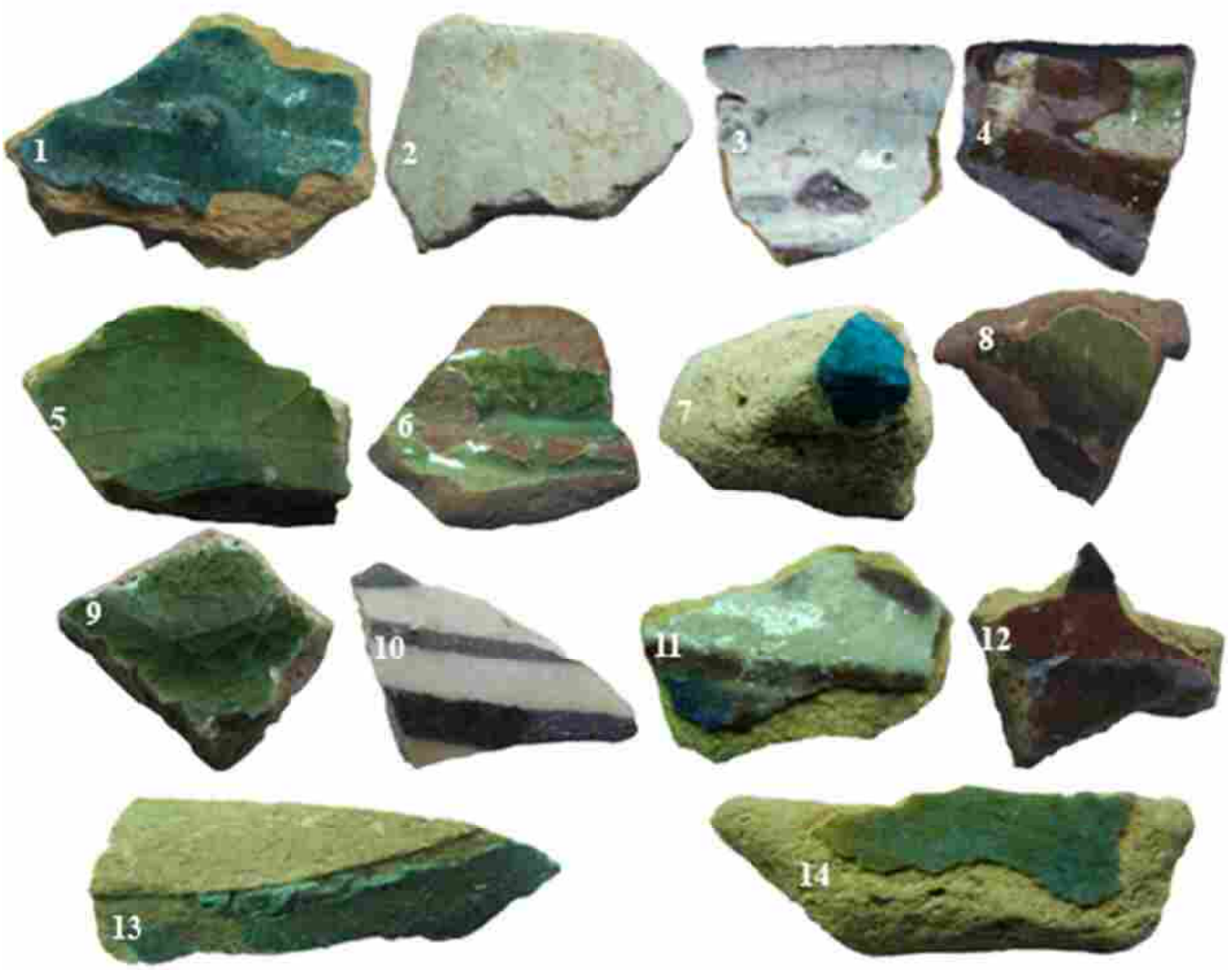

Fig.1 shows ceramic samples from Mamlūk period found in Al-Fūsțāṭ, Egypt.

\section{MATERIALS AND METHODS}

Samples: 14 samples of ceramic studied in this work. The samples are from the excavation of Al-Fūstāṭt in Cairo from the Mamlūk period (1250 - 1517 AC) fig.1. The samples were prepared for analysis by scratching powder and selection of fresh grains under microscope orientation on a diamond cell.

X-Ray Diffraction: Non-destructive XRD analysis was carried out with a Ni filter, $\mathrm{Cu}-\mathrm{K} \alpha$ radiation $1.54056 \AA$ at $40 \mathrm{kV}, 25 \mathrm{~mA}$, and $0.05^{\circ} / \mathrm{sec}$. It had a high-resolution graphite monochromatic, rotating sample holder and a proportional detector. Measurements were carried out on the samples in the range $0^{\circ}<2 \theta<70^{\circ}$ in steps of $0.02^{\circ}$. 
FTIR-ATR spectroscopy: FTIR measurements conducted in ATR (Attenuated Total Reflectance) mode, a diamond cell used as sample holder in the wavelength range of 4000$500 \mathrm{~cm}^{-1}$ with a spectral resolution of $8 \mathrm{~cm}^{-1}$ and 32 scans. A background of the clean diamond cell performed for each analysis undertaken, two diamond cells used to get a thin and flat sample and good results, six measurements were done on each sample.

Polarizing Light Microscope: Used for studying the optical properties of minerals in the ceramic's thin-sections, it is an effective method in mineralogical compositions analysis. Although polarizing microscope is a traditional technique, it is an efficient and valuable that helps in determining the firing temperature through minerals changes and new phases formed during ceramic raw materials firing or post-deposit minerals . In this work the thinsections were studied by Optiphot 2 Nikon.

\section{RESULTS AND DISCUSSION}

\section{XRD}

The mineralogical compositions of shards identified by XRD depend on the chemistry of starting raw materials, firing temperature and the firing atmosphere. XRD patterns of the studied samples show thepresence of common minerals in the shards: quartz $\mathrm{SiO}_{2}$, hematite $\mathrm{Fe}_{2} \mathrm{O}_{3}$, halite $\mathrm{NaCl}$, calcite, and microcline. The presence of these minerals comes from the raw materials; clay and additives and deposits of halite crystals inside the pores as postburials minerals. XRD results confirm the presence of quartz in high amounts in all samples; it assigned quartz in $60-80 \%$. On the other hand, firing minerals which have been formed at estimated temperature identified by XRD. Two different types of firing materials were formed, meta-stable and stable firing minerals, both types start formation at $800-950$ ${ }^{\circ} \mathrm{C}$. Gehlenite $\left(\mathrm{Ca}_{2} \mathrm{Al}\left(\mathrm{AlSiO}_{7}\right)\right.$ is meta-stable compound present in eight samples. It formed in the system of $\mathrm{CaO}-\mathrm{Al}_{2} \mathrm{O}_{3}-\mathrm{SiO}_{2}$ and appears when calcite $\mathrm{CaCO}_{3}$ decarbonizes from the reaction between meta-kaolinite and calcium oxide. This reaction occurs above $850^{\circ} \mathrm{C}$ (Eq.1). Wollastonite $\mathrm{CaSiO}_{3}$ is abundant in the ceramic body, it forms from the reaction between carbonates and quartz at $850^{\circ} \mathrm{C}$ (Eq. 2). Wollastonite found in three samples. Both gehlenite and wollastonite considered intermediate compounds, which became unstable in presence of $\mathrm{SiO}_{2}$ and react to give anorthite $\left(\mathrm{CaAl}_{2} \mathrm{Si}_{2} \mathrm{O}_{8}\right)$ above $850{ }^{\circ} \mathrm{C}$ (Eq. 3$)^{13}$. Diopside $\mathrm{CaMgSi}_{2} \mathrm{O}_{6}$ formed from the reaction between carbonate and quartz at $850-900^{\circ} \mathrm{C}$, it is stable minerals, diopside were found in twelve samples (Eq.4). Spinel $\mathrm{MgAl}_{2} \mathrm{O}_{4}$ results from the reaction between $\mathrm{CaO}$ and/or $\mathrm{MgO}$ with clay minerals and $\mathrm{SiO}_{2}$, which considered one of the most common firing minerals in high firing temperature ceramic it observed in ceramic body above $850^{\circ} \mathrm{C}$. (Fig.2)

$$
\begin{aligned}
& 3 \mathrm{SiO}_{2} \mathrm{Al}_{2} \mathrm{O}_{3}+6 \mathrm{CaO} \rightarrow 3 \mathrm{Ca}_{2} \mathrm{Al}_{2} \mathrm{SiO}_{7} \text { (gehlenite) } \\
& \mathrm{CaCO}_{3}+\mathrm{SiO}_{2} \rightarrow \mathrm{CaSiO}_{3} \text { (Wollastonite) } \\
& \mathrm{Ca}_{2} \mathrm{Al}_{2} \mathrm{SiO}_{7}+\mathrm{Al}_{2} \mathrm{Si}_{2} \mathrm{O}_{7}+\mathrm{SiO}_{2} \rightarrow 2 \mathrm{CaAl}_{2} \mathrm{Si}_{2} \mathrm{O}_{8} \text { (Anorthite) } \\
& 2 \mathrm{SiO}_{2}+\mathrm{CaMg}\left(\mathrm{CO}_{3}\right)_{2} \rightarrow \mathrm{CaMgSi}_{2} \mathrm{O}_{6}(\text { Diopside })+2 \mathrm{CO}
\end{aligned}
$$

13 - Jordán et al, Firing Transformations of Tertiary Clays Used in the Manufacturing of Ceramic, p. 20, 87.

- 170 - Estimation of firing temperature of Islamic ceramic using XRD and FTIR 


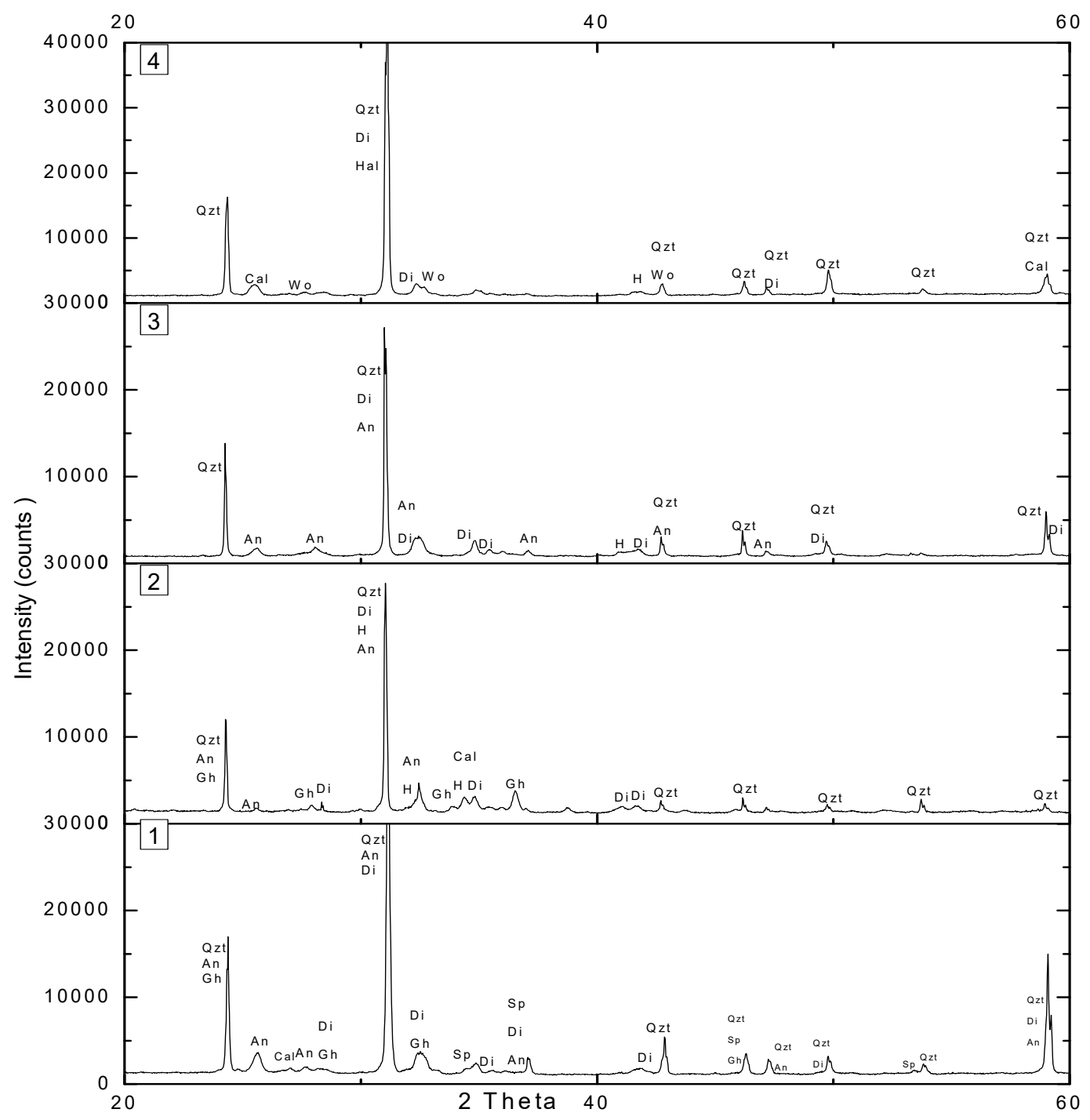

Fig.2 XRD pattern of ceramic from Al-Fūsțât, Cairo, shows presence of primary minerals and firing minerals, where; Quartz (Qzt), Calcite (Cal), Wollastonite (Wol), Halite (Hal), Diopside (Di), Anorthite (An), Hematite(H), Gehlenite (Gh) and Spinel (Sp).

\section{FTIR}

FTIR-ATR spectral analysis recorded typical spectra from ceramic, the characteristic frequencies of the present minerals identified and reported in this study. Quartz $\mathrm{SiO}_{2}$ assigned in all studied samples. It is the main component of the Islamic ceramic in Egypt, absorption peaks of quartz detected at $778 \mathrm{~cm}^{-1}, 697 \mathrm{~cm}^{-1}, 680 \mathrm{~cm}^{-1}$. The FTIR results agree with the results of XRD. New phases identified by FTIR, meta-stable and stable firing minerals established in the studied samples. The new phases are gehlenite, wollastonite, diopside, and spinel, they are formed from the start raw materials upon firing of clay mixture to specific temperatures. Characteristic bands of gehlenite showed absorption peaks at $1011,915,856,807,667 \mathrm{~cm}^{-1}$. While calcite $\mathrm{CaCO}_{3}$ identified in two samples, absorption bands of calcite observed at $876,847,712 \mathrm{~cm}^{-1}$. Calcite presence in the studied samples comes as reformed when the object buried in humid soil. This secondary calcite can be formed from gehlenite (Eq.5). The polarizing microscope studies the optical 
properties the ceramic compositions, samples thin section used to determine secondary calcite grains in ceramic matrix fig.3. The microscopic observations carried on samples thin sections shows the presence of calcite in secondary form, the calcite is present in fine grains and coating the inside pores walls. ${ }^{14}$

$4 \mathrm{Ca}_{2} \mathrm{Al}_{2} \mathrm{SiO}_{7}+18 \mathrm{H}_{2} \mathrm{O} \rightarrow \mathrm{CaAl}_{2} \mathrm{Si}_{4} \mathrm{O}_{12} \cdot 2 \mathrm{H}_{2} \mathrm{O}+7 \mathrm{Ca}(\mathrm{OH})_{2}+6 \mathrm{Al}(\mathrm{OH})_{3}$

Additional firing minerals identified by FTIR; diopside identified in all studied samples, the typical spectrum of diopside shows absorption peaks at $965,920,865 \mathrm{~cm}^{-1}$. It is stable mineral starts to appear in low concentration at $900^{\circ} \mathrm{C}$. Wollastonite is formed from the reaction between carbonate and quartz, it appears as gehlenite at $850{ }^{\circ} \mathrm{C}^{15}$. The absorption peaks of wollastonite present at $1017,681,644 \mathrm{~cm}^{-1}$. Spinel phase identified in the samples at bands $680,588 \mathrm{~cm}^{-1}$ Fig. 4.

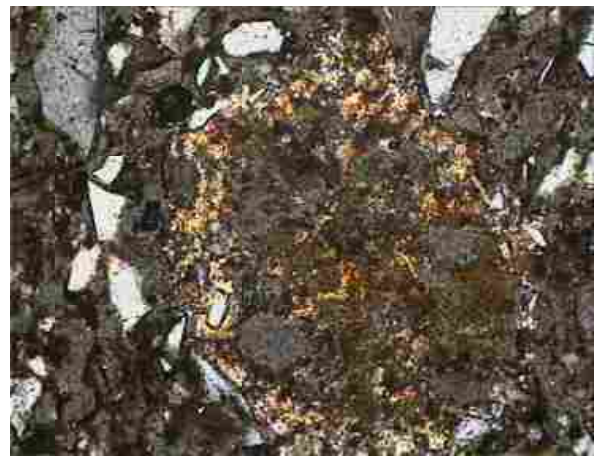

Fig.3. Petrographic image shows the presence of secondary calcite formed after the burial of the ceramic objects.

\section{CONCLUSION}

The analytical results obtained in this work indicate the presence of two types of minerals in the Islamic ceramic found in Al-Fūsțât, Cairo, raw minerals and firing minerals. The raw minerals are the compound used as starting materials but didn't transform into new phases. However, part acts in the thermal transformations such as quartz and hematite.. The presence of calcite in the studied samples relate to post-burial minerals in a secondary form as found in polarizing microscope samples. Above $850{ }^{\circ} \mathrm{C}$ new phases formed such as gehlenite, wollastonite, diopside, and spinel, these minerals support the hypothesis that the calcite present in the studied samples is the secondary calcite. The firing minerals show that the studied samples produced from $\mathrm{Ca}$ - rich clay with a significant content of hematite. The presence of meta-stable beside stable minerals in the same sample indicate that firing length was not enough to completely transform meta stable into stable minerals. The firing temperature of ceramic from Al-Fūsțât was done above $850-900{ }^{\circ} \mathrm{C}$, although public ceramic produced during the Mamlūk period, it was characterized by its quality of production.

\footnotetext{
14 - Sadek, Multi-Analytical approach for the study of glazed ceramics, pp. 65-71.

15 - De Benedetto et al, Infrared spectroscopy in the mineralogical characterization of ancient ceramics, pp.177-186
}

- 172 - Estimation of firing temperature of Islamic ceramic using XRD and FTIR 

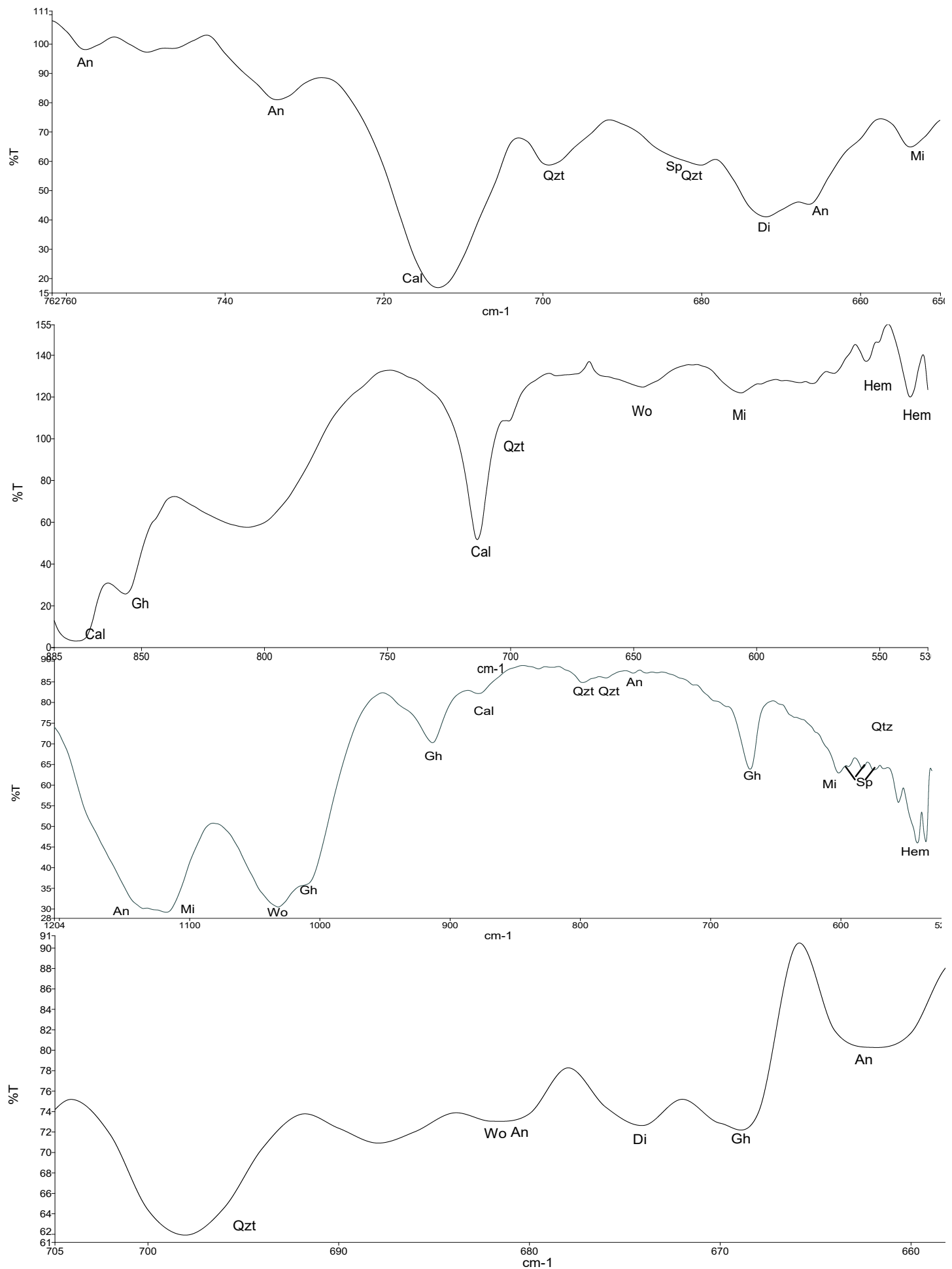

Fig.4 FTIR spectra acquired on ceramic from Cairo (Mamlūk period), where; Quartz (Qzt), Calcite (Cal), Wollastonite (Wol), Halite (Hal), Diopside (Di), Anorthite (An), Hematite(H), Gehlenite (Gh) and Spinel (Sp). 


\section{REFERENCES}

- Chatfield (M.), "Tracing firing technology through clay properties in Cuzco, Peru," Journal of Archaeological Science, vol. 37, Issue 4 (2010), pp. 727-736.

- De Benedetto (G.), Laviano (L.) Sabbatini (C.), "Infrared spectroscopy in the mineralogical characterization of ancient pottery," Journal of Cultural Heritage, vol.3, issue 3 (2002), pp.177186.

- Goodwin (W.) - Hollenback (K.), "Assessing Techniques for the Estimation of Original Firing Temperatures of Plains Ceramics: Experimental and Archaeological Results," Journal of Archaeological, Ethnographic and Experimental Studies, Vol.8, Issue 2 (2016), pp.180-204.

- Henderson (J.), The science and archaeology of materials, Rutledge, 2000.

- Jordán (Manuel), Sanfeliu (Teofilo), de la Fuente (Calvo), , "Firing Transformations of Tertiary Clays Used in the Manufacturing of Ceramic Tile Bodies" Applied Clay Science, Vol. 20, Issues $1-2$, pp.87-95

- Maniatis (Y.), "The emergence of ceramic technology and its evolution as revealed with the use of scientific techniques," In from Mine to Microscope: Advances in the Study of Ancient Technology, Andrew Short land, Ian C. Freestone and ThiloRehren (eds.), Oxford: Oxbow Books, 2009. pp. 11-28.

- Nicholson (P.), "Kilns and Firing Structures," In UCLA Encyclopedia of Egyptology, Willeke Wendrich (ed.), University of California 2010, pp.1-10

- Rapp (G.), 2009, Archaeomineralogy, Springer-Verlag Berlin Heidelberg.

- Rasmussen (K.), de la Fuente (G.), Bond (A.), Mathiesen (K.) and Vera (S.), "Pottery firing temperatures: a new method for determining the firing temperature of ceramics and burnt clay,"

Journal of Archaeological Science, 39 (2012), pp. 1705-1716.

- Rhodes (D.), Clay and glazes for the potters, London: Chilton Book Co. 1996.

- Rice (P.), Pottery analysis, The university of Chicago press 1987.

- Sadek (H.), "Multi-Analytical approach for the study of glazed ceramics from El-Fusțat, Egypt," Mediterranean Archaeology and Archaeometry, Vol. 16, No. 3 (2016), pp. 65-71.

- Shepard (A.), Ceramics for archaeologists, Washington: Carnegie institution of Washington, 1980.

- Stuart (B.), Infrared Spectroscopy: Fundamentals and Applications, Chichester, West Sussex, England; Hoboken, NJ:J. Wiley, 2004.

- Velraj (G.), Janaki (K.), Musthafa (M.), Pandalanivel (R.), "Estimation of firing temperature of some archaeological ceramics sherds excavated recently in Tamilnadu, India". Spectrochimica Acta Part A: Molecular and Biomolecular Spectroscopy .Vol. 72, (2008), pp730-733.

- 174 - Estimation of firing temperature of Islamic ceramic using XRD and FTIR 